\title{
U.N. Declaration on the Elimination of Violence against Women
}

\section{ARTICLE I :}

For the purposes of this Declaration, the term "violence against women" means any act of gender-based violence that results in, or is likely to result in, physical, sexual or psychological harm or suffering to women, including threats of such acts, coercion or arbitrary deprivation of liberty, whether occurring in public or in private life.

ARTICLE 2:

Violence against women shall encompass, but is not limited to the following:

(a) Physical, sexual and psychological violence occurring in the family, including battering, sexual abuse of female children in the household, dowry-related violence, marital rape, female genital mutilation and other traditional practices harmful to women, non-spousal violence and violence related to exploitation;

(b) Physical, sexual and psychological violence occurring within the general community, including rape, sexual abuse, sexual harassment and intimidation at work, in educational institutions and elsewhere, trafficking in women and forced prostitution;

(c) Physical, sexual and psychological violence perpetrated or condoned by the state, wherever it occurs. 


\section{ARTICLE 3:}

Women are entitled to the equal enjoyment and protection of all human rights and fundamental freedoms in the political, economic, social, cultural, civil or any other field. These rights include, inter alia:

(a) The right to life;

(b) The right to equality;

(c) The right to liberty and security of person;

(d) The right to equal protection under the law;

(e) The right to be free from all forms of discrimination;

(f) The right to the highest standard attainable of physical and mental health;

(g) The right to just and favourable conditions of work;

(h) The right not to be subjected to torture, or other cruel, inhuman or degrading treatment or punishment.

United Nations, General Assembly, 85th plenary meeting, 20 December 1993; A/RES/48/I04 http://www.un.org/documents/ga/res/48/a48rio4.htm 